\title{
Penerapan Analytic Network Process untuk Pemilihan Kantor Akuntan Publik
}

\author{
Kaslani $^{\mathrm{a}}{ }^{1}$, Odi Nurdiawan ${ }^{\mathrm{b} 2}$, Ade Irma Purnamasari ${ }^{\mathrm{c} 3}$ \\ aProgram Studi Komputerisasi Akuntansi STMIK IKMI Cirebon, Jln Perjuangan No 10 B Majasem Kesambi Kota \\ Cirebon \\ bProgram Studi Manajemen Informatika STMIK IKMI Cirebon, Jln Perjuangan No 10 B Majasem Kesambi Kota \\ Cirebon \\ cProgram Studi Teknik Informatika STMIK IKMI Cirebon, Jln Perjuangan No 10 B Majasem Kesambi Kota Cirebon \\ ${ }^{1} \mathrm{kaslani}$ ikmi.ac.id \\ ${ }^{2}$ odinurdiawan2020@gmail.com \\ 3irma2974@yahoo.com
}

\begin{abstract}
Abstrak
Profesi akuntan publik semakin berkembang seiring dengan pertumbuhan Kantor Akuntan Publik (KAP) dimana kebutuhan perusahaan publik yang membutuhkan jasa akuntan publik untuk menilai laporan keuangannya. Banyaknya kebutuhan akan jasa akuntan publik disebabkan oleh keinginan perusahaan publik untuk menyajikan laporan keuangan secara wajar, transparan dan akuntabel. Kendala yang dihadapi adalah bagaimana memilih Kantor akuntan publik yang memiliki kapabilitas tinggi dengan 8 (delapan) kriteria pertama Reputasi, kedua Kualitas personel yang ditugaskan, ketiga Macam jasa yang ditawarkan, keempat Sikap bebas tidak memihak., kelima Tarif jasa yang diberikan, keenam Jarak tempat akuntan publik dengan klien, ketujuh Pengalaman kantor akuntan publik, kedelapan Hubungan kantor publik dengan klien, dan memiliki 3 (tiga) Pertama KAP Kaslani dan Rekan, KAP Indra dan Rekan, KAP Santosa dan Rekan. Analytic Network Process akan diperoleh nilai masing-masing alternatif yang akan dipilih dalam penelitian ini. Perangkinan dalam penelitian ini menggunakan konsep semakin tinggi nilai yang diperoleh maka semakin baik rankingnya. Berdasarkan hasil perhitungan menggunakan algoritma Analytic network process hasil perangkingan dengan kode A01 Nama KAP Kaslani dan Rekan dengan Nilai RAW (asal) sebesar 0.1803 dan Nilai Normal Sebesar $36.06 \%$. kode A02 Nama KAP Santosa dan Rekan dengan Nilai RAW (asal) sebesar 0.1667 dan Nilai Normal Sebesar $33.34 \%$. kode A03 Nama KAP Indra dan Rekan dengan Nilai RAW (asal) sebesar 0.153 dan Nilai Normal Sebesar 30.59 \%. Maka dengan hasil perangkingan diatas dapat direkomendasikan dengan 8 klriteria dan 3 alternatif serta hasil perangkingan peneliti memilih Kantor Akuntan Publik Kaslani dan rekan.
\end{abstract}

Kata kunci : Kantor Akuntan Publik, Analytic Network Process, Akuntansi.

\section{Application of the Analytic Network Process for the Selection of a Public Accounting Firm Abstract}

The public accounting profession is growing along with the growth of the Public Accounting Firm (KAP) where the need for public companies that require public accounting services to assess their financial statements. The high demand for public accounting services is caused by the desire of public companies to present financial reports in a fair, transparent and accountable manner. The obstacle faced is how to choose a highly capable public accounting firm with 8 (eight) criteria, first is reputation, second is quality of assigned personnel, three types of services are offered, fourth is free attitude of impartiality, fifth is tariff for services provided, sixth is distance of place public accountants with clients, seventh experience of public accounting firms, eighth Public office relations with clients, and have 3 (three) First KAP Kaslani and Partners, KAP Indra and Partners, KAP Santosa and Partners. The Analytic Network Process value will be obtained for each alternative that will be selected in this study. The ranking in this study uses the concept of the higher the value obtained, the better the ranking. Based on the results of calculations using the Analytic network process algorithm, the ranking results with code A01 Name KAP Kaslani and Partners with a RAW (original) value of 0.1803 and a normal value of $36.06 \%$. Code A02 Name of KAP Santosa and Partners with a RAW (original) value of 0.1667 and a normal value of 33.34\%. Code A03 Name of KAP Indra and Partners with a RAW Value (original) of 0.153 and a Normal Value 
of 30.59\%. So with the results of the ranking above, it can be recommended with 8 criteria and 3 alternatives and the results of the ranking of researchers choosing Kaslani Public Accounting Firm and colleagues.

Keywords : Public Accounting Firm, Analytic Network Process, Accounting.

\section{Pendahuluan}

Kantor Akuntan Publik (KAP) adalah badan usaha yang didirikan dan menjalankan kegatan usahanya diatur berdasarkan Undang-Undang Nomor 5 Tahun 2011 tentang Akuntan Publik [1], Peraturan Pemerintah Republik Indonesia Nomor 20 Tahun 2015 Tentang Praktik Akuntan Publik dan Peraturan Menteri Keuangan Nomor 17/Pmk.01/2008 Tentang Jasa Akuntan Publik [2].

Profesi akuntan publik semakin berkembang seiring dengan pertumbuhan Kantor Akuntan Publik (KAP) dimana kebutuhan perusahaan publik yang membutuhkan jasa akuntan publik untuk menilai laporan keuangannya. Banyaknya kebutuhan akan jasa akuntan publik disebabkan oleh keinginan perusahaan publik untuk menyajikan laporan keuangan secara wajar, transparan dan akuntabel. Karena laporan keuangan merupakan suatu media utama untuk mengkomunikasikan informasi keuangan kepada pihak-pihak di luar entitas. Laporan keuangan merupakan bentuk pertanggungjawaban dan penyampaian informasi keuangan suatu perusahaan atau organisasi kepada pihak-pihak yang membutuhkan, eksternal maupun internal[3]. Disinilah pentingnya peran Kantor Akuntan Publik (KAP) dalam sistem pelaporan akuntansi dan auditing untuk proses pemenuhan kontrak sosial perusahaan dengan pihak stakeholders [4]. Keandalan laporan keuangan sangat dibutuhkan oleh pihak stakeholder karena berpengaruh terhadap pengambilan keputusan

Penelitian sebelumnya yang telah dilakukan oleh Susan dan Trisnawati (2011) yang menguji 5 faktor (pergantian manajemen, opini akuntan, kesulitan keuangan perusahaan, ukuran KAP dan presentase perubahan ROA) yang dianggap berpengaruh terhadap pemilihan KAP pada perusahaan manufaktur di Indonesia periode tahun 2004-2009 dan hasilnya variabel pergantian manajemen dan ukuran KAP yang berpengaruh secara signifikan terhadap pergantan KAP, sedangkan opini akuntan, kesulitan keuangan perusahaan dan presentase perubahan ROA tidak berpengaruh [5].

Dalam kurun waktu tahun 2007 sampai dengan 2014 pertumbuhan KAP terus mengalami peningkatan. Hal ini tercermin pada tahun 2007 tercatat 893 izin akuntan publik dan pada tahun 2014 tercatat 1053 izin akuntan publik. Pertumbuhan KAP selama kurun waktu tersebut tercermin dalam grafik berikut ini:

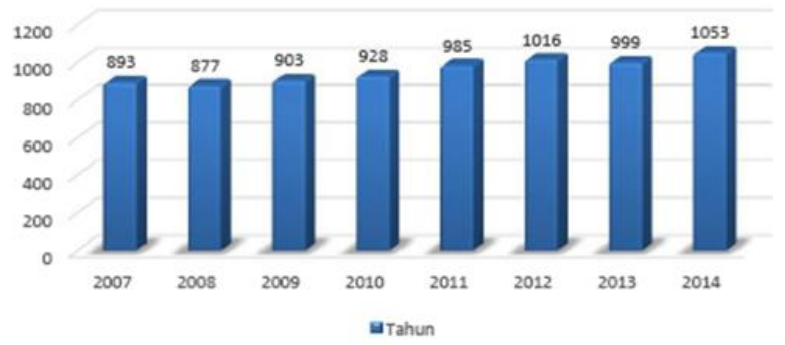

Gambar 1. Grafik Perkembangan KAP di Indonesia Tahun 2007-2014 [6]
Berdasarkan Direktori PPK Kementrian Keuangan RI Tahun 2016 yang diterbitkan oleh Institut Akuntan Publik Indonesia (IAPI) bekerjasama dengan Kementrian Keuangan Republik Indonesia Sekretariat Jenderal Pusat Pembinaan Profesi Keuangan (PPPK), per tanggal 31 Januari 2016 Akuntan Publik (AP) seluruh Indonesia sebanyak 1.229 orang dan Kantor Akuntan Publik (KAP) yang telah memperoleh izin dari Menteri Keuangan sebanyak 539 KAP terdiri 405 Kantor Pusat, 134 Kantor Cabang, dari jumlah tersebut terdapat 4 (empat) KAP diklasifikasikan sebagai Big Four [7][8]. Tujuan penelitian ini agar memberikan rekomendasi kantor akuntan publik yang memiliki kapabilitas yang sangat baik.

\section{Metodologi}

Metodologi yang digunakan dalam penelitian dalam penerapan Analytic Network Process (ANP) pemilihan kantor akuntan publik. berikut Langkahlangkah penelitian yang dilakukan dalam pemecahan masalah tersebut dapat dilihat dalam diagram alir penelitian seperti pada

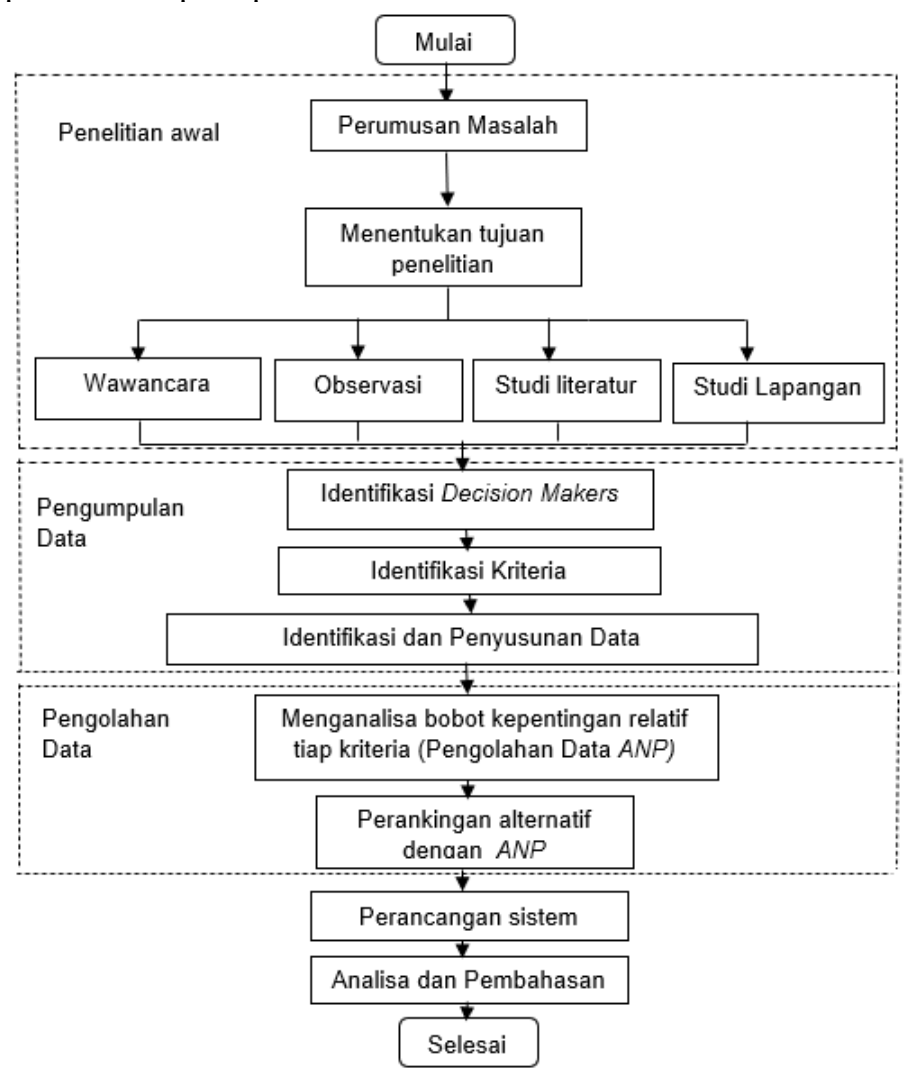

Gambar 2. Diagram Alir

\section{A. Penelitian Awal}

Penelitian memiliki beberapa tahapan di antaranya [9] [10]:

1) Rumusan masalah

Pada tahap ini merupakan tahap awal dari metodologi penelitian. Rumusan masalah di dalam penelitian yakni 
Bagaimana pemilihan kantor akuntan publik menggunakan metode Analytic Network Process (ANP).

2) Menentukan tujuan penelitian

Pada tahap ini setelah diketahui masalah yang akan diselesaikan maka mentukan tujuan yang akan dicapai yaitu mendapatkan kantor akuntan publik dengan menggunakan metode Analytic Network Process (ANP).

3) Observasi

Pada tahapan ini observasi dilakukan dengan melakukan pengamatan dan pemahaman serta mencatat hal-hal penting dan mengumpulkan data-data mengenai kriteria-kriteria untuk pemilihan kantor akuntan publik.

4) Wawancara

Pada tahap wawancara memiliki tujuan untuk mengumpulkan informasi yang dibutuhkan dalam menerapkan metode Analytic Network Process (ANP) untuk memilih kantor akuntan publik.

5) Studi literatur

Pada tahap ini akan dilakukan dengan mecari dan memahami terkait teori-teori yang akan diselesaikan dalam penelitian ini. Tahap ini dilakukan dengan memahami penelitian-penelitian terdahulu, buku, publikasi ilmiah dan internet terkait dengan pemilihan kantor akuntan publik.

\section{B. Pengumpulan Data}

\section{1) Identifikasi Decision Makers}

Pada tahapan ini dilakukan untuk mendapatakan pengambil keputusan yang terlibat dalam pemilihan kantor akuntan publik.

2) Identifikasi Kriteria

Pada tahap ini dilakukan dengan cara memahami penelitian-penelitian terdahulu terkait kriteria-kriteria yang berpengaruh dalam suatu pemilihan bibit padi unggul. Adapun kriteria sebagai berikut :

a) Reputasi.

b) Kualitas personel yang ditugaskan.

c) Macam jasa yang ditawarkan.

d) Sikap bebas tidak memihak.

e) Tarif jasa yang diberikan.

f) Jarak tempat akuntan publik dengan klien.

g) Pengalaman kantor akuntan publik.

h) Hubungan kantor publik dengan klien.

3) Identifikasi dan Penyusunan Data

Setelah kriteria yang akan digunakan sudah diidentifikasi, maka tahap selanjutnya adalah penyusunan instrumen yang akan digunakan untuk pengambilan data untuk penelitian ini. Penyusuan kriteria yang akan digunakan dalam penelitian ini berupa perbandingan berpasangan

\section{Pengolahan Data}

Pengolaan data terdiri dari beberapa tahapan diantaranya [11] [12] [13]:

1) Matriks perbandingan berpasangan yang menunjukkan keterkaitan. Dalam ANP pendekatan dalam pengambilan keputusan tetap didasarkan kepada keputusan untuk mendapatkan prioritas sebagaimana halnya metode AHP.

2) Perhitungan bobot elemen Bobot yang dicari dinyatakan dalam vektor $\mathrm{W}=[\mathrm{WI}, \mathrm{W} 2, \mathrm{~W} 3, \ldots, \mathrm{Wn}]$.
Nilai Wn menyatakan bobot relatif kriteria An terhadap keseluruhan set kriteria pada sub sistem tersebut. Pada situasi penilaian yang sempurna (teoritis) maka didapatkan hubungan seperti pada persamaan (2.1) :

aik = aij. ajk untuk semua $\mathrm{i}, \mathrm{j}, \mathrm{k}$......(2.1)

Matriks yang diperoleh adalah matriks yang konsisten. aij dapat dinyatakan di dalam vektor $\mathrm{W}$ sebagai persamaan (2.2) :

aij $=$ wi $/$ wj i,j $=1,2,3, \ldots$.n.

Dari persamaan (2.2) diatas dapat dibuat persamaan (2.3) (2.4) (2.5) :

$$
\begin{aligned}
& \text { aij.wj /wi }=1, \mathrm{i}=1,2,3, \ldots \ldots . \mathrm{n} . \ldots . .(2.3) \\
& \sum_{n=j}^{i} \text { aij. } w j / w i=n \quad i=1,2,3, \mathrm{n}(2.4) \\
& \sum_{n=j}^{i} \text { aij.wj }=n w i \quad i=1,2,3, \mathrm{n}(2.5)
\end{aligned}
$$

Dalam teori matriks rumus di atas adalah persamaan karakteristik dengan $\mathrm{W}$ merupakan Eigenvector dari matriks A dengan nilai eigen sebesar $n$. Bila ditulis secara lengkap maka persamaan tersebut akan terlihat seperti pada Gambar 3 berikut ini :

$$
\left(\begin{array}{cccc}
\frac{w_{1}}{w_{1}} & \frac{w_{1}}{w_{2}} & \ldots \ldots . . . \frac{w_{1}}{w_{3}} \\
\frac{w_{2}}{w_{1}} & \frac{w_{2}}{w_{2}} & \ldots \ldots . . & \frac{w_{2}}{w_{3}} \\
\ldots & \ldots & \ldots \\
\frac{w_{n}}{w_{1}} & \frac{w_{n}}{w_{2}} & \ldots \ldots . . & \frac{w_{n}}{w_{3}}
\end{array}\right)\left(\begin{array}{l}
W_{1} \\
W_{2} \\
W_{n}
\end{array}\right)=n\left(\begin{array}{l}
W_{1} \\
W_{2} \\
W_{n}
\end{array}\right)
$$

Gambar 3. Eigenvector

Pada umumnya ada beberapa nilai eigenvector yang bersesuaian yang memenuhi persamaan di atas. Variabel $n$ pada persamaan (2.3) (2.4) (2.5) dapat digantikan dengan sebuah vektor A,seperti persamaan (2.6) :

$$
\mathrm{A} W=\lambda W \ldots \ldots \ldots \ldots \ldots . . .(2.6)
$$

Dimana $\lambda=(\lambda 1, \lambda 2, \ldots, \lambda \mathrm{n})$ Setiap $\lambda$.yang memenuhi persamaan di atas dinamakan sebagai eigenvalue, sedangkan vektor yang memenuhi persamaan (2.6) tersebut dinamakan sebagai eigenvector. Bila matriks A diketahui dan ingin diperoleh nilai $\mathrm{W}$, maka dapat diselesaikan melalui persamaan (2.7) :

$$
(\mathrm{A}-\mathrm{nI}) W=0 \text {........(2.7) }
$$

Persamaan ini dapat menghasilkan solusi yang tidak nol (jika dan hanya jika) n merupakan eigenvalue dari A dan $\mathrm{W}$ adalah eigenvectornya. Setelah eigenvalue matriks perbandingan A tersebut diperoleh. misalnya: $\lambda 1$. $\mathrm{A} 2, \lambda \mathrm{n}$ dan berdasarkan matriks A yang mempunyai keunikan yaitu aij=1. dengan $1=1.2, \ldots, \mathrm{n}$, maka seperti persamaan (2.8) :

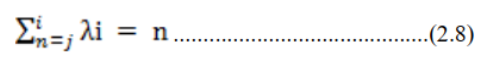

Di sini semua eigenvalue bernilai nol. kecuali satu yang tidak no1 yaitu eigenvalue maksimum. Kemudian jika penilaian yang dilakukan konsisten akan diperoleh 
eigenvalue maksimum dari A yang bernilai n. Untuk mendapatkan $\mathrm{W}$, maka dapat dilakukan dengan mensubtitusikan harga eigenvalue maksimum pada persamaan (2.9) :

$\mathrm{AW}=\lambda$ maks $\mathrm{W}$,

selanjutnya persamaan tersebut dapat diubah menjadi persamaan (2.10):

$$
\text { A }-\lambda \text { maks } 1 W=0 \text {. . }
$$

untuk memperoleh nilai nol maka yang harus dilakukan seperti persamaan (2.11) :

$$
\mathrm{A}-\lambda \text { maks I }=0 \text {. }
$$

Berdasarkan persamaan dapat diperoleh harga $\lambda$ maks dengan memasukkan persamaan $\lambda$ maks dan ditambah dengan persamaan , maka akan diperoleh bobot masing-masing elemen operasi $\mathrm{Wi}$, dengan $\mathrm{i}=1,2, \ldots, \mathrm{n}$ yang merupakan eigenvector yang berkesesuaian dengan eigenvalue maksimum [14].

3) Perhitungan rasio konsistensi Tingkat ketidak konsistenan pada respon di sebut dengan rasio ketidak konsistenan (CI) yang perhitungannya adalah sebagai berikut:

$$
\mathrm{CI}=(\lambda \text { maks }-\mathrm{N}) /(\mathrm{N}-1)
$$

Keterangan :

$\lambda$ maks $=$ eigenvalue maksimum

$\mathrm{n}=$ ukuran matriks

$\mathrm{CI}=$ indeks konsistensi

Perbandingan antara CI dan RI untuk suatu matriks didefinisikan sebagai rasio konsistensi (CR)

$\mathrm{CR}=R I / C I$.... (2.13)

Keterangan :

$R I=$ indeks rasio

$\mathrm{CI}=$ indeks konsistensi

$\mathrm{CR}=$ rasio konsistensi

4) Membentuk Cluster Matrix. Membuat cluster matrix dengan cara membentuk matrik perbandingan yang bobot tiap cluster-nya telah ditentukan sebelumnya, lalu setiap nilai dari matriks perbandingan antar cluster dihitung eigenvector-nya, dan cluster matrix didapat dari nilai eigenvector tersebut(Ibrahim, 2013).

5) Pembentukan super matriks dan analisis Super matriks berisikan submatriks yang terdiri atas hubunganhubungan antara dua tingkat pada model grafis. Asumsikan bahwa komponen $\mathrm{k}$, dinyatakan dengan $\mathrm{Ck}, \mathrm{k}=1, \ldots, \mathrm{N}$ dengan $\mathrm{nk}$ elemen, yang dinyatakan dengan $\mathrm{Ck} 1, \mathrm{Ck} 2, \ldots, \mathrm{Ckn}$ sebagaimana diperlihatkan dalam supermatriks pada Gambar 4.

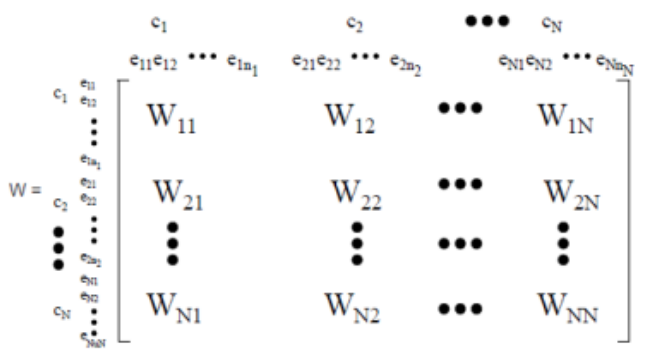

Gambar 4. super matriks

Matrik hasil Perbandingan berpasangan direpresentasikan kedalam bentuk vertikal dan horizontal berbentuk matrik yang bersifat stochatic disebut sebagai supermatriks 3 tahap supermatriks [15]:

1) Supermatriks tanpa bobot (Unweighted Super Matrix) Membuat unweighted superm atrix dengan cara memasukkan semua eigenvector yang telah dihitung sebelumnya ke dalam sebuah supermatriks.

2) Supermatriks terbobot (Weighted Super Matrix) Membuat weighted supermatrix dengan cara melakukan perkalian setiap isi unweighted supermatrix terhadap matriks perbandingan kriteria (cluster matrix), sehingga setiap kolom pada weighted Super Matrix memiliki jumlah satu.

3) Supermatriks batas (Limitting Super Matrix) Membuat limiting supermatrix dengan cara mengalikan weighted Super Matrix dengan dirinya sendiri lalu hasil perkalian dijadikan bobot untuk dinormalisasikan dan di cari nilai eigenvector-nya. Ketika bobot pada setiap kolom memiliki nilai yang sama, maka limit matrix telah stabil dan proses perkalian matrik dihentikan.

\section{Perancangan Sistem}

Perancangan perangkat lunak merupakan pengembangan model sistem yang berpedoman pada analisa sistem. Tujuan dari perancangan sistem adalah pembuatan rincian sehingga sistem dapat dipahami oleh user yang akan menggunakannya.

\section{E. Analisa dan Pembahasan}

Pada tahap ini akan dilakukan dengan menganalisis dari hasil pengolahan data yang sudah dilakukan pada tahap sebelum.

\section{PEMBAHASAN DAN HASIL}

\section{A. Pembahasaan}

Pada penelitian ini penentuan bobot kriteria dilakukan dengan menggunakan metode AHP, sedangkan untuk tahap perankingan dengan menggunakan metode ANP, Berdasarkan tahapan tahapan pada metode penelitian maka Penerapan Analytic Network Process untuk Pemilihan Kantor Akuntan Publik sebagai Berikut :

1) Alternatif

TABEL I

ALTERNATIF

\begin{tabular}{|c|c|l|}
\hline No & Kode & \multicolumn{1}{c|}{ Nama } \\
\hline 1 & A1 & KAP Kaslani dan Rekan \\
\hline 2 & A2 & KAP Indra dan Rekan \\
\hline 3 & A3 & KAP Santosa dan Rekan \\
\hline
\end{tabular}

2) Kriteria

TABEL II

KRITERIA

\begin{tabular}{|c|c|l|}
\hline No & Kode & \multicolumn{1}{|c|}{ Nama } \\
\hline 1 & C1 & Reputasi Kantor Akuntan \\
\hline 2 & C2 & Kualitas Personel yang Ditugaskan \\
\hline 3 & C3 & Macam Jasa yang Ditawarkan \\
\hline 4 & C4 & Sikap Bebas Tidak Memihak \\
\hline
\end{tabular}




\begin{tabular}{|c|c|l|}
\hline No & Kode & \multicolumn{1}{|c|}{ Nama } \\
\hline 5 & C5 & Tarif Jasa yang Diberikan \\
\hline 6 & C6 & $\begin{array}{l}\text { Jarak antara Kantor Akuntan dengan } \\
\text { Tempat Klien }\end{array}$ \\
\hline 7 & C7 & $\begin{array}{l}\text { Pengalaman Kantor Akuntan di Masa } \\
\text { Lalu }\end{array}$ \\
\hline 8 & C8 & $\begin{array}{l}\text { Hubungan Kantor Akuntan Publik } \\
\text { dengan Klien }\end{array}$ \\
\hline
\end{tabular}

3) Nilai Alternatif

TABEL III NILAI ALTERNATIF

\begin{tabular}{|c|c|c|c|}
\hline \multicolumn{4}{|c|}{ KRITERIA C1 } \\
\hline & $\mathrm{A} 1$ & $\mathrm{~A} 2$ & $\mathrm{~A} 3$ \\
\hline $\mathrm{A} 1$ & 1 & 2 & 3 \\
\hline $\mathrm{A} 2$ & 0.5 & 1 & 2 \\
\hline $\mathrm{A} 3$ & 0.333333333 & 0.5 & 1 \\
\hline Total & 1.833333333 & 3.5 & 6 \\
\hline
\end{tabular}

\begin{tabular}{|c|c|c|c|c|c|}
\hline & A1 & A2 & A3 & Prioritas & Consistency Measure \\
\hline A1 & 0.54 & 0.57 & 0.5 & 0.53 & 3.014725569 \\
\hline A2 & 0.27 & 0.28 & 0.3 & 0.29 & 3.008495146 \\
\hline A3 & 0.18 & 0.14 & 0.1 & 0.16 & 3.004405286 \\
\hline \multirow{5}{*}{} & & $\begin{array}{c}\text { Consistency } \\
\text { Index }\end{array}$ & 0.004604333 \\
\cline { 3 - 5 } & Ratio Index & 0.58 \\
\hline & $\begin{array}{c}\text { Consistency } \\
\text { Ratio }\end{array}$ & 0.007938506 \\
\cline { 3 - 5 } & Consistency & Konsisten \\
\cline { 4 - 5 }
\end{tabular}

\section{4) Nilai Kriteria}

TABEL IV

KRITERIA

\section{ALTERNATIF A 1}

\begin{tabular}{|c|c|c|c|}
\hline & $\mathrm{C} 1$ & $\mathrm{C} 2$ & $\mathrm{C} 3$ \\
\hline $\mathrm{C} 1$ & 1 & 5 & 7 \\
\hline $\mathrm{C} 2$ & 0.2 & 1 & 4 \\
\hline $\mathrm{C} 3$ & 0.142857143 & 0.25 & 1 \\
\hline Total & 1.342857143 & 6.25 & 12 \\
\hline
\end{tabular}

\begin{tabular}{|c|c|c|c|c|c|}
\hline & $\mathrm{C} 1$ & $\mathrm{C} 2$ & $\mathrm{C} 3$ & Prioritas & $\begin{array}{c}\text { Consistency } \\
\text { Measure }\end{array}$ \\
\hline $\mathrm{C} 1$ & 0.74 & 0.8 & 0.58 & 0.709338061 & 3.264722546 \\
\hline $\mathrm{C} 2$ & 0.14 & 0.16 & 0.33 & 0.214089835 & 3.093308304 \\
\hline $\mathrm{C} 3$ & 0.10 & 0.04 & 0.08 & 0.076572104 & 3.022361399 \\
\hline \multirow{5}{*}{} & $\begin{array}{c}\text { Consistency } \\
\text { Index }\end{array}$ & 0.063398708 \\
\cline { 3 - 5 } & Ratio Index & 0.58 \\
\cline { 3 - 5 } & $\begin{array}{c}\text { Consistency } \\
\text { Ratio }\end{array}$ & 0.109308118 \\
\cline { 3 - 5 } & Consistency & Tidak konsisten \\
\cline { 3 - 5 }
\end{tabular}

5) Perhitungan

a) Supermatriks

TABEL V

SUPER MATRIX

\begin{tabular}{|c|c|c|c|c|c|c|c|}
\hline $\begin{array}{c}\text { Super } \\
\text { matriks }\end{array}$ & A1 & A2 & A3 & C1 & C2 & C3 & Total \\
\hline A1 & 1 & 0 & 0 & 0.539 & 0.608 & 0.062 & 2.209 \\
\hline A2 & 0 & 1 & 0 & 0.297 & 0.272 & 0.236 & 1.806 \\
\hline A4 & 0 & 0 & 1 & 0.164 & 0.12 & 0.701 & 1.985 \\
\hline C1 & 0.709 & 0.074 & 0.061 & 1 & 0 & 0 & 1.844 \\
\hline C2 & 0.214 & 0.643 & 0.216 & 0 & 1 & 0 & 2.073 \\
\hline C3 & 0.077 & 0.283 & 0.723 & 0 & 0 & 1 & 2.082 \\
\hline Total & 2 & 2 & 2 & 2 & 2 & 2 & \\
\hline
\end{tabular}

\section{b) Weighted Supermatrix}

TABEL V

WEIGHTED SUPERMATRIX

\begin{tabular}{|c|c|c|c|c|c|c|c|}
\hline $\begin{array}{c}\text { Weighted } \\
\text { Super } \\
\text { matrix }\end{array}$ & A1 & A2 & A3 & C1 & C2 & C3 & Total \\
\hline A1 & 0.5 & 0 & 0 & 0.269 & 0.304 & 0.031 & 1.105 \\
\hline A2 & 0 & 0.5 & 0 & 0.149 & 0.136 & 0.118 & 0.903 \\
\hline A4 & 0 & 0 & 0.5 & 0.082 & 0.06 & 0.351 & 0.993 \\
\hline C1 & 0.355 & 0.037 & 0.031 & 0.5 & 0 & 0 & 0.922 \\
\hline C2 & 0.107 & 0.322 & 0.108 & 0 & 0.5 & 0 & 1.037 \\
\hline C3 & 0.038 & 0.141 & 0.362 & 0 & 0 & 0.5 & 1.041 \\
\hline Total & 1 & 1 & 1 & 1 & 1 & 1 & \\
\hline
\end{tabular}

\section{c) Limit Supermatrix}

TABEL VI WEIGHTED SUPERMATRIX

\begin{tabular}{|c|c|c|c|c|c|c|}
\hline Limit & A1 & A2 & A3 & C1 & C2 & C3 \\
\hline A1 & 0.197 & 0.197 & 0.197 & 0.197 & 0.197 & 0.197 \\
\hline A2 & 0.134 & 0.134 & 0.134 & 0.134 & 0.134 & 0.134 \\
\hline A4 & 0.169 & 0.169 & 0.169 & 0.169 & 0.169 & 0.169 \\
\hline C1 & 0.16 & 0.16 & 0.16 & 0.16 & 0.16 & 0.16 \\
\hline C2 & 0.165 & 0.165 & 0.165 & 0.165 & 0.165 & 0.165 \\
\hline C3 & 0.175 & 0.175 & 0.175 & 0.175 & 0.175 & 0.175 \\
\hline
\end{tabular}

\section{d) Perangkingan}

TABEL VII PERANGKINGAN

\begin{tabular}{|c|c|c|}
\hline Kode & Raw & Normal \\
\hline A1 & 0.197 & $39 \%$ \\
\hline A2 & 0.134 & $27 \%$ \\
\hline A4 & 0.169 & $34 \%$ \\
\hline
\end{tabular}




\section{B. Hasil}

Hasil perancangan sistem pada penelitian ini sebagai berikut :

\section{1) Tampilan Awal}

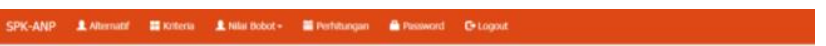

Aplikasi Penentuan Kantor Akuntan Publik dengan Motede Analytic Network Process

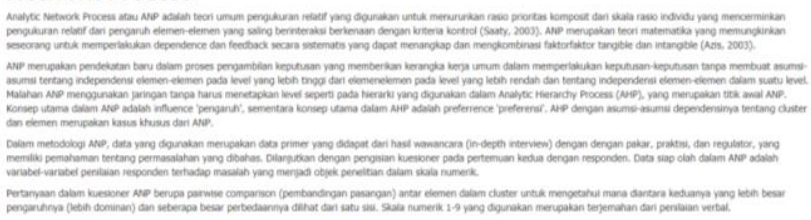

Gambar 5. Tampilan utama

Berdasarkan gambar 5 diatas menjelaskan bahwa hasil sistem home pemilihan Kantor Akunatan Publik dengan menggunakan Algoritma Analytic Network Process.

\section{2) Tampilan Kriteria}

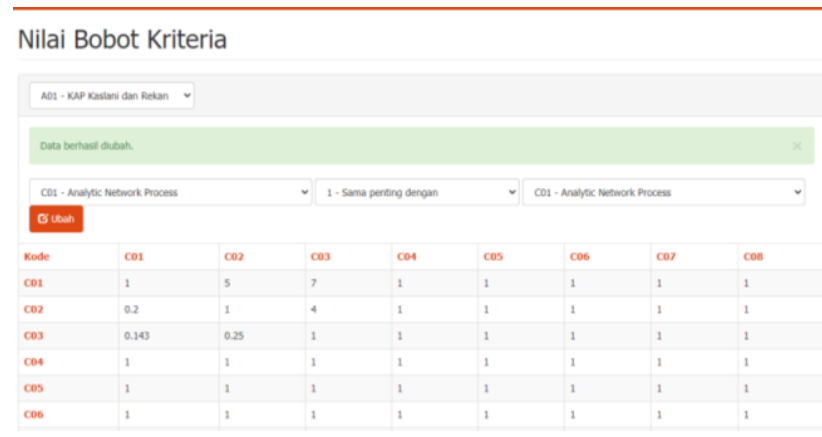

Gambar 6. Tampilan Kriteria

Berdasarkan gambar 6 diatas nilai kriteria pada penelitian ini memiliki 8 (delapan) pertama Reputasi, kedua Kualitas personel yang ditugaskan, ketiga Macam jasa yang ditawarkan, keempat sikap bebas tidak memihak, kelima Tarif jasa yang diberikan, keenam Jarak tempat akuntan publik dengan klien, ketujuh Pengalaman kantor akuntan publik, kedelapan Hubungan kantor publik dengan klien. Kemudian kriteria menunjukkan keterkaitan

\section{3) Tampilan Alternatif}

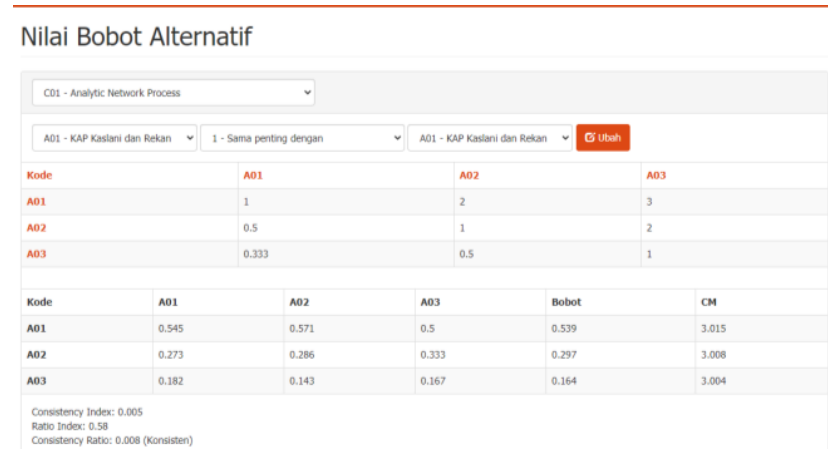

Gambar 7. tampilan Alternatif
Berdasarkan gambar 7 diatas menjelaskan bahwa Nilai bobot Alternatif, Alternatif pada penelitian ini memiliki 3 (tiga) Pertama KAP Kaslani dan Rekan, KAP Indra dan Rekan, KAP Santosa dan Rekan. Kemudian alternatif menunjukkan keterkaitan

\section{4) Tampilan Supermatrix}

\begin{tabular}{|c|c|c|c|c|c|c|c|c|c|c|c|}
\hline \multicolumn{12}{|c|}{ Supermtix } \\
\hline & A01 & N02 & no3 & co1 & $c 02$ & $\cos$ & $\cos$ & $\cos$ & 1006 & $\mathrm{cor}$ & $\cos$ \\
\hline No1 & 1 & 。 & 。 & 0.599 & 0.068 & 0.0623 & ב3ב3 & 0.3333 & 0.333 & 0.330 & 0.333 \\
\hline a02 & 。 & 1 & 。 & 0.2973 & 0.221 & 0.2364 & 0.5333 & 0.3533 & 0.3333 & 0.333 & 0.3333 \\
\hline ness & 。 & 。 & 1 & 0.1638 & 0.1199 & 0.0013 & 0.033 & 0.330 & 0.2303 & 0.333 & 0.3030 \\
\hline $\cos$ & 0.2049 & 0.0005 & 0.0058 & 1 & 。 & 。 & 。 & 。 & 。 & 0 & 。 \\
\hline$c 02$ & 0.1226 & 0.1868 & 0.1245 & 。 & 1 & 。 & 。 & 。 & 。 & 。 & 。 \\
\hline $\cos$ & 0.0911 & o.1.128 & 0.21 & 。 & 。 & 1 & 。 & 。 & 。 & 。 & 。 \\
\hline $\mathrm{COS}$ & 0.1163 & 0.118 & 0.1153 & 。 & 。 & 。 & 1 & 。 & 。 & 。 & 。 \\
\hline $\cos$ & 0.1163 & 0.118 & 0.1153 & 。 & 。 & 。 & 。 & 1 & 。 & 。 & 。 \\
\hline $\cos$ & 0.1163 & o.1. & 0.1153 & 。 & 。 & 。 & 。 & 。 & 1 & 。 & 。 \\
\hline $\cos$ & 0.1163 & 0.118 & 0.1153 & 。 & 。 & 。 & 。 & 。 & 。 & 1 & 。 \\
\hline$C 0 \theta^{\circ}$ & 0.1163 & 0.118 & 0.1153 & 。 & 。 & 。 & 。 & 。 & 。 & 。 & 1 \\
\hline Total & 2 & 2 & 2 & 2 & 2 & 2 & 2 & 2 & 2 & 2 & 2 \\
\hline
\end{tabular}

Gambar 8. Tampilan Supermatrix

Berdasarkan gambar 8 diatas menjelaskan bahwa Supermatriks tanpa bobot (Unweighted Super Matrix) unweighted superm atrix dengan memasukkan semua eigenvector yang telah dihitung sebelumnya ke dalam sebuah supermatriks.

\section{5) Tampilan Weight supermatrix}

\begin{tabular}{|c|c|c|c|c|c|c|c|c|c|c|c|}
\hline \multicolumn{12}{|c|}{ both } \\
\hline & no1 & 102 & ${ }^{103}$ & cor & $\cos$ & $\cos$ & $\cos$ & $\cos$ & $c 06$ & $\mathrm{COI}$ & $\cos$ \\
\hline no1 & 0.5 & 。 & 。 & 0.2695 & 0.304 & 0.0311 & 0.1667 & 0.1667 & 0.1667 & 0.1607 & 0.1600 \\
\hline N02 & . & 0.5 & 。 & 0.1456 & 0.136 & 0.1182 & 0.1667 & 0.1667 & 0.1667 & 0.1667 & 0.1667 \\
\hline nos & 。 & 。 & 0.5 & 0.0819 & 0.06 & 0.3507 & 0.1667 & 0.1667 & $0.160 \mathrm{~J}$ & 0.1667 & 0.1667 \\
\hline cor & 0.1024 & 0.0453 & 0.044 & 0.5 & 。 & 。 & 。 & 。 & 0 & 。 & 0 \\
\hline 002 & 0.0513 & 0.0934 & 0.0622 & 。 & 0.5 & 。 & 。 & 。 & 。 & 。 & 。 \\
\hline $\cos$ & 0.0455 & 0.0664 & 0.105 & 0 & 。 & 0.5 & 。 & 。 & 。 & 0 & 0 \\
\hline $\cos$ & 0.0581 & 0.059 & 0.057 & 0 & . & 。 & 0.5 & 。 & 。 & 。 & 。 \\
\hline $\cos$ & 0.0581 & 0.059 & $0.05 \pi$ & 0 & 。 & 。 & 。 & 0.5 & 0 & 。 & 。 \\
\hline $\cos$ & 0.0581 & 0.059 & $0.05 n$ & 0 & 。 & - & 。 & 。 & 0.5 & 0 & 0 \\
\hline$\infty 07$ & 0.0581 & 0.059 & 0.057 & 0 & $\circ$ & 。 & 。 & 。 & 0 & a. & 。 \\
\hline 008 & 0.0581 & 0.059 & $0.05 n$ & 0 & 。 & 。 & 0 & 。 & 。 & 。 & 0.5 \\
\hline Totat & 1 & 1 & 0.99999999999999 & 1 & 1 & 1 & 1 & 1 & 1 & 1 & 1 \\
\hline
\end{tabular}

Gambar 9. Weight supermatrix

Berdasarkan gambar 9 diatas menjelaskan Supermatriks terbobot (Weighted Super Matrix) weighted supermatrix dengan melakukan perkalian setiap isi unweighted supermatrix terhadap matriks perbandingan kriteria (cluster matrix), sehingga setiap kolom pada weighted Super Matrix memiliki jumlah satu

6) Tampilan Limit Supermatrik

\begin{tabular}{|c|c|c|c|c|c|c|c|c|c|c|c|}
\hline \multicolumn{12}{|c|}{ Unit Supermatixix : 68 kat } \\
\hline & no1 & N02 & no3 & col & $\mathrm{cos}$ & $\cos$ & $\cos$ & $\cos$ & 106 & cor & $\cos$ \\
\hline No1 & 0.18003 & 0.18003 & 0.1803 & 0.1803 & 0.1903 & 0.1003 & 0.18003 & 0.1003 & 0.1803 & 0.1803 & 0.1903 \\
\hline 102 & 0.153 & 0.153 & 0.153 & 0.153 & 0.153 & 0.153 & 0.153 & 0.153 & 0.153 & 0.153 & 0.153 \\
\hline No3 & 0.1667 & 0.1667 & 0.160 & 0.1667 & 0.166 & 0.1667 & 0.1600 & 0.160 & 0.1667 & 0.1667 & 0.1667 \\
\hline cor & 0.0656 & 0.0656 & 0.0556 & 0.0656 & 0.0556 & 0.0656 & 0.0656 & 0.0556 & 0.0056 & 0.0056 & 0.0556 \\
\hline $\cos$ & 0.0714 & 0.074 & 0.0714 & 0.0714 & 0.0714 & 0.0714 & 0.0714 & 0.0714 & 0.0714 & 0.0714 & 0.0714 \\
\hline $\cos$ & 0.0718 & 0.0718 & 0.0718 & 0.0718 & 0.0718 & 0.0716 & 0.0718 & 0.0718 & 0.0718 & 0.0718 & 0.0718 \\
\hline $\mathrm{cos}$ & 0.0502 & 0.0502 & 0.0502 & 0.0582 & 0.0502 & 0.0502 & 0.0562 & 0.0582 & 0.0502 & 0.0502 & 0.0582 \\
\hline $\cos$ & 0.0582 & 0.0582 & 0.0582 & 0.0582 & 0.0582 & 0.0582 & 0.0582 & 0.0582 & $0.05 \mathrm{a} 2$ & 0.0582 & 0.0502 \\
\hline $\cos$ & 0.0522 & 0.0582 & 0.0582 & 0.0582 & 0.0582 & 0.0582 & 0.0562 & 0.0582 & 0.0562 & 0.0562 & 0.0502 \\
\hline$\infty$ & 0.0582 & 0.0582 & 0.0582 & 0.0582 & 0.0582 & 0.0582 & 0.0562 & 0.0582 & 0.0582 & 0.0562 & 0.0582 \\
\hline$\infty$ & 0.0582 & 0.0582 & 0.0582 & 0.0582 & 0.0502 & 0.0582 & 0.0582 & 0.0582 & 0.0582 & 0.0582 & 0.0582 \\
\hline reat & 1 & 1 & 1 & 1 & 1 & 1 & 1 & 1 & 1 & 1 & 1 \\
\hline
\end{tabular}

Gambar 10. Limit Supermatrik 
Besarakan Gamabar 10 diatas menjelaskan tentang Supermatriks batas (Limitting Super Matrix) limiting supermatrix dengan mengalikan weighted Super Matrix dengan dirinya sendiri lalu hasil perkalian dijadikan bobot untuk dinormalisasikan dan di cari nilai eigenvector-nya. Ketika bobot pada setiap kolom memiliki nilai yang sama, maka limit matrix telah stabil dan proses perkalian matrik dihentikan ketika sudah mencapai 68 kali.

\section{7) Tampilan Perangkingan}

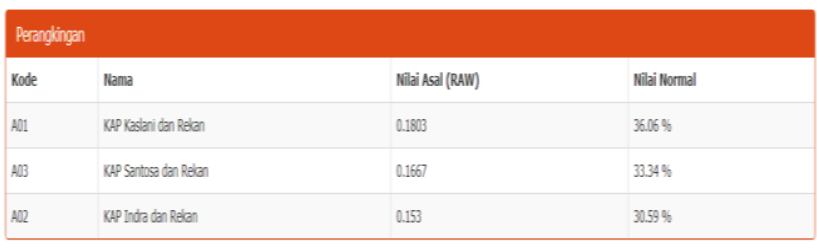

Gambar 11. Perangkingan

Berdasarkan gambar 11 diatas menjelaskan tentang perangkingan, setelah dilakukan limiting supermatrix maka dapat diperoleh hasil perangkingan dengan kode A01 Nama KAP Kaslani dan Rekan dengan Nilai RAW (asal) sebesar 0.1803 dan Nilai Normal Sebesar $36.06 \%$. kode A02 Nama KAP Santosa dan Rekan dengan Nilai RAW (asal) sebesar 0.1667 dan Nilai Normal Sebesar $33.34 \%$. kode A03 Nama KAP Indra dan Rekan dengan Nilai RAW (asal) sebesar 0.153 dan Nilai Normal Sebesar $30.59 \%$. Maka dengan hasil perangkingan diatas dapat direkomendasikan dengan 8 klriteria dan 3 alternatif serta hasil perangkingan peneliti memilih Kantor Akuntan Publik Kaslani dan rekan.

\section{KESIMPULAN}

Peneliti dapat menyimpulkan Kriteria yang digunakan pada penelitian ini 8 (delapan) kriteria pertama Reputasi, kedua Kualitas personel yang ditugaskan, ketiga Macam jasa yang ditawarkan, keempat Sikap bebas tidak memihak., kelima Tarif jasa yang diberikan, keenam Jarak tempat akuntan publik dengan klien, ketujuh Pengalaman kantor akuntan publik, kedelapan Hubungan kantor publik dengan klien.

1) Alternatif yang diambil ialah kantor akuntan publik yang berada diwilayah kota cirebon Alternatif pada penelitian ini memiliki 3 (tiga) Pertama KAP Kaslani dan Rekan, KAP Indra dan Rekan, KAP Santosa dan Rekan.

2) Berdasarkan hasil perhitungan menggunakan algoritma Analytic network process hasil perangkingan dengan kode A01 Nama KAP Kaslani dan Rekan dengan Nilai RAW (asal) sebesar 0.1803 dan Nilai Normal Sebesar $36.06 \%$. kode A02 Nama KAP Santosa dan Rekan dengan Nilai RAW (asal) sebesar 0.1667 dan Nilai Normal Sebesar $33.34 \%$. kode A03 Nama KAP Indra dan Rekan dengan Nilai RAW (asal) sebesar 0.153 dan Nilai Normal Sebesar $30.59 \%$

3) Maka dengan hasil perangkingan diatas dapat direkomendasikan dengan 8 klriteria dan 3 alternatif serta hasil perangkingan peneliti memilih Kantor Akuntan Publik Kaslani dan rekan.

\section{UCAPAN TERIMA KASIH}

Ucapan terima kasih kami sampaikan kepada Direktorat Riset dan Pengabdian Masyarakat Kementerian Riset dan Teknologi / Badan Riset dan Inovasi Nasional atas hibah penelitian dosen pemula dan Kementerian Pendidikan dan Kebudayaan Republik Indonesia. Terima kasih pula kami sampaikan pula kepada LPPM STMIK IKMI Cirebon

\section{DAFTAR PUSTAKA}

[1] Undang-Undang Republik Indonesia. 2011. Undang-Undang Republik Indonesia Nomor 5 Tahun 2011 tentang "Akuntan Publik"

[2] Menteri Keuangan. 2008. Peraturan Menteri Keuangan Republik Indonesia Nomor 17/PMK.01/2008 pasal 3 tentang "Jasa Akuntan Publik": Jakarta.

[3] Jensen, M., C., dan W. Meckling, 1976. "Theory of the firm: Managerial behavior, agency cost and ownership structure", Journal of Finance Economic 3:305- 360.

[4] Wijayani, Evi Dwi dan Indira Januarti. “Analisis Faktor-Faktor yang Mempengaruhi Perusahaan di Indonesia Melakukan Auditor Switching". Simposium Nasional Akuntansi 14, Aceh. 2011

[5] Susan dan Trisnawat. "Analisis Faktor-Faktor yang Mempengaruhi Perusahaan Melakukan Auditor Switch" Jurnal Bisnis dan Akuntansi. Vol. 13 No 2 Agustus 2011

[6] Pusat Pembinaan Profesi Keuangan (PPPK) Sekretariat Jenderal Kementerian Keuangan. (2019). Diunduh tanggal 12 April 2020. Diunduh dari http://pppk.kemenkeu.go.id/Sanksi/Details/2046.

[7] Institut Akuntan Publik Indonesia (IAPI). (2016). SA 200: Standar Audit. http://iapi.or.id/Iapi/detail/153

[8] Institut Akuntan Publik Indonesia (IAPI). (2011). Standar Profesional Akuntan Publik. Jakarta: Salemba Empat.

[9] Kusrini. 2007. Konsep dan Aplikasi Sistem Pendukung Keputusan. Penerbit Andi, Yogyakarta

[10] Kusumadewi, Sri. 2003. Artificial Intelligence (Teknik dan Aplikasinya). Yogyakarta: Graha Ilmu.

[11] Saaty, T. Lorie. 1993. Pengambilan Keputusan Bagi Para Pemimpin, Proses Hirarki Analitik untuk Pengambilan Keputusan dalam Situasi yang Kompleks.Pustaka Binama Pressindo.

[12] Saaty, T. Lorie. 1999. Fundamental of the analytic network process . University of Pittsburgh

[13] Saaty, T. Lorie. 2003. Decision Making With the AHP: why is the principal eigenvector necessary. University of Pittsburgh

[14] Saaty, TL., 1988. The Analytic Hierarchy Process. Pittsburgh: University of Pittsburgh.

[15] Saaty, TL., 2001. Decision Making For Leaders. University of Pittsburgh, RWS Publication 